\title{
Tourism area life cycle analysis in San Miguel de Allende Guanajuato
}

\section{Análisis del ciclo de vida de los destinos turísticos en San Miguel de Allende, Guanajuato}

\author{
SONDA-DE LA ROSA, Ricardo $\dagger^{*}$, RUIZ-LANUZA, Agustin and ALCUDIA-ROCHA, Josefina \\ Universidad del Caribe, Mexico.
}

Universidad de Guanajuato, Mexico.

ID $1^{\text {sr }}$ Author: Ricardo, Sonda-de la Rosa / ORC ID: 0000-0002-6788-4758, Researcher ID Thomson: AAN-4749-2021, arXiv Author ID: rsonda, CVU CONACYT ID: 416187

ID $1^{\text {st }}$ Co-author: Agustin, Ruiz-Lanuza / ORC ID: 0000-0002-9604-8310, CVU CONACYT ID: 222896

ID $2^{\text {nd }}$ Co-author: Josefina, Alcudia-Rocha / ORC ID: 0000-0002-5953-2859

DOI: $10.35429 /$ EJRP.2021.12.7.7.21

Received January 15, 2021; Accepted June 30, 2021

\begin{abstract}
The Tourism Area Life Cycle model is in itself one of the most used tools to analyze tourist competitiveness. In order to solve the problem of the lack of a comprehensive tourism strategy in the city of San Miguel de Allende that can comply with sustainable development, this research establishes its objective in the documentary analysis of the evolution of the tourism indicators that it has presented in destination for its analysis and comparison with the model of the Tourism Area Life Cycle model, identifying in the corresponding stage and thereby establishing relevant tourism planning strategies. The document was developed with a descriptive quantitative approach that used documentary review and analysis techniques of various tourist indicators of the destination. In conclusion, it is highlighted that the city of San Miguel de Allende has individual indicators in various stages of the life cycle: Development, Consolidation, and Decline; globally, it has been in the Stagnation stage since 2015 with prominent features of Decline and Rejuvenation. This results in an obvious need to define sustainable tourism management strategies to boost the destination's competitiveness effectively.
\end{abstract}

Turistic development, Tourist indicators, Life Cycle Indicar

\section{Resumen}

El modelo del Ciclo de Vida de los Destinos Turísticos es en sí mismo una de las herramientas más utilizadas para analizar la competitividad turística. Con el fin de resolver el problema de la falta de una estrategia integral turística en la ciudad de San Miguel de Allende que pueda cumplir con un desarrollo sustentable, esta investigación establece su objetivo en el análisis documental de la evolución de los indicadores turísticos para su análisis y comparación con el modelo del Ciclo de Vida de los Destinos Turísticos identificado en la etapa correspondiente y con ello establecer estrategias pertinentes de planificación turística. El documento se desarrolló con un enfoque cuantitativo descriptivo haciendo uso de técnicas de revisión y análisis documental de indicadores turísticos. Como conclusión, se destaca que la ciudad de San Miguel de Allende cuenta con indicadores individuales en diversas etapas del ciclo de vida, los hay en Desarrollo, en Consolidación y en Declive; de manera global, se encuentra en la etapa de Estancamiento desde el año 2015 con rasgos evidentes de Declive y de Rejuvenecimiento. Esto resulta en un aporte para definir las estrategias de gestión turística sustentable para impulsar de manera efectiva la competitividad del destino.

Desarrollo turístico, Indicadores, Ciclo de vida

Citation: SONDA-DE LA ROSA, Ricardo, RUIZ-LANUZA, Agustin and ALCUDIA-ROCHA, Josefina. Tourism area life cycle analysis in San Miguel de Allende Guanajuato. ECORFAN Journal-Republic of Peru. 2021. 7-12:7-21.

\footnotetext{
* Correspondence to Author (Email: rsonda@ucaribe.edu.mx)

$\dagger$ Researcher contributing first author.
} 


\section{Introduction}

One of the references for the analysis of tourism competitiveness is the one proposed by (Butler, 1980) called: Life cycle model of tourist destinations (CVDT) that has supported the determination of the most consistent strategies in current tourism planning. This analysis has been carried out in countries such as: Greece (Michailidou, Vlachokostas, Moussiopoulos, \& Maleka, 2016), Malaysia (Shida, Abdul, Badaruddin, \& Azizi, 2015), Korea (Lee \& Weaver, 2014), Spain ( García-Ayllon, 2015) and Chile (García, Reinares, \& Armelini, 2013) managing to establish as a result the appropriate tourist positioning or innovation strategies regarding the stage in which the destination was diagnosed, confirming that said model is useful as a basis theory in tourism development today.

According to data from the World Tourism Organization (UNWTO, 2019), at the end of 2018, the number of global travelers was 1,401 billion, which represented an increase of 9.7\% compared to the previous year, which meant a spills for the concept of international tourism of 1,451 billion dollars. Mexico as a country received 22.3 million international tourists, of which 21 million were intern (Banco de México, 2021). Tourist mobility in the country's territory was variable but constant, especially in colonial destinations and sun and beach destinations.

The analysis of Mexican tourist destinations under the CVDT model of Butler (1980) is not new, destinations such as Ixtapa Zihuatanejo (Osorio, Deverdum, Mendoza, \& Benitez, 2019), Cozumel (Segrado, 2011) and Puerto Vallarta (Aguilar, 2009), they have done it. Through historical indicators of supply and demand in products and services offered to national and international tourists, they have proposed tourist strategies that are now a reality. However, until now these destinations are oriented to the sun and beach segment, which, although it is one of the most attractive for tourism, the colonial city segment should not be relegated, making it pertinent to carry out an exercise that includes cultural destinations and historical and that for their national and international heritage are demanded by national and international tourism.
The most popular colonial destinations in Mexico are: Zacatecas; Oaxaca de Juárez, Morelia, Mérida, San Francisco de Campeche, Puebla de Zaragoza, Santiago de Querétaro, the city of Guanajuato and of course San Miguel de Allende. San Miguel de Allende is a city of the colonial era recognized for its Spanish Baroque architecture, active artistic scene and cultural festivals, with 171,000 inhabitants, it is part of the Bajío region and has a great wealth of preColumbian ancestors, offering an endless number of attractions in the modern cultural and historical environment of the same place.

The basis of this research work is that the city of San Miguel de Allende is a destination considered mature in relation to Butler's CVDT model and that it is in the consolidation stage, however, there is no comprehensive analysis of tourism indicators that can determine it and establish it in the corresponding stage, be it in (development, consolidation, stagnation or even, decline or repositioning).

Analyzing tourist destinations from the perspective of the CVDT model requires a series of exhaustive and in-depth observations, not only analysis of economic indicators, since these are usually the only indicators that are used as input to establish government management policies, but on the contrary, consider other indicators to make a comprehensive analysis that allows to make comprehensive proposals for sustainable, environmental and social development and thereby determine the most precise location of the life stage of the destination in this proven theoretical model.

The main problem is based on the lack of an inclusive tourism strategy in San Miguel de Allende, which can be systematized and structured based on the assessment of the current situation and the assessment of the future situation. For this reason, it is proposed to start with a qualitative and descriptive analysis of its current situation, which will help to build an ideal future and visualize sustainable tourism development from this process.

The idea is that with this study it is possible to avoid over-impacting the levels of load capacity, problems in the quality of the service offered, so as to guarantee the satisfaction of tourists and visitors that is presented in a traditional way when a tourist destination is handled in an ordinary way. 
Interpreting the indicators under the Butler model guarantees that tourism strategies are aligned, preventing their decline and, above all, implementing sustainable innovation in a way that generates a positive impact and achieves self-sufficient tourism.

In this way, the objective of this article is to analyze the evolution of tourist indicators that have influenced the present condition of the city of San Miguel de Allende, comparing it with the CVDT model for the correct location in the evolution stage to generate specific strategies of positioning, consolidation or rescue of the cultural destination.

Through the use of qualitative and descriptive methods, the relevant texts of the tourism supply and demand indicators of San Miguel de Allende from scientific articles, development plans and databases were reviewed and analyzed.

The article is divided into four parts: the first part analyzes the CVDT model, the characteristics and the criticisms; the second part describes the research methodology; the third part contains the conclusions drawn from the analysis of the information collected; and the fourth, the indicators that place San Miguel de Allende in its evolutionary stage and the author's final reflections.

\section{Comprehensive life cycle analysis of tourist destinations}

The life cycle of a destination is one of the most relevant topics in the analysis of tourism competitiveness, because it shows the evolution of the destination and, despite its limitations, it can help define a comprehensive development strategy. The CVDT model originated from the studies of Richard Butler (1980), who was guided by the conceptual elements of Christaller (1963) and the theory of Vernon and Wells (1966), in relation to the life cycle of a commercial product. Butler integrated a model based on tourism as the main element of the system and the relationship with the locals of the destinations. Combining the definitions of Plog (1973), Doxey (1975) and Cohen (1979), he developed a model that can understand the different stages of any tourist destination over time, establishing it as a management and planning tool. The CVDT model consists of seven stages, which are described below, see Table 1:

\begin{tabular}{|c|c|}
\hline Situation & Stage \\
\hline $\begin{array}{l}\text { The tourist destination has just been } \\
\text { discovered, and few travelers with an } \\
\text { exploration profile visit it. It is mainly } \\
\text { visited by nearby towns that seek their } \\
\text { attractions that are of natural or cultural } \\
\text { origin. Accessibility is limited, as is the } \\
\text { supply of infrastructure and tourism } \\
\text { and support services. }\end{array}$ & Exploration \\
\hline $\begin{array}{l}\text { The number of tourists increases as } \\
\text { their origin becomes regional. Group } \\
\text { trips are organized. Local residents } \\
\text { participate in an artisanal way in the } \\
\text { provision of tourist services and } \\
\text { products. There is a defined timeframe } \\
\text { and the government starts financing to } \\
\text { improve the destination's infrastructure }\end{array}$ & Involvement \\
\hline $\begin{array}{l}\text { The growth of tourists grows } \\
\text { significantly, mass trips are present, the } \\
\text { tourist offer grows in quality and } \\
\text { quantity. The external investment to the } \\
\text { locality begins, as well as the } \\
\text { promotion of the destination } \\
\text { nationwide. An image of the } \\
\text { destination is created where together } \\
\text { the government and private initiative } \\
\text { invest in it. }\end{array}$ & Developing \\
\hline $\begin{array}{l}\text { Tourists have different profiles, the } \\
\text { local economy comes mainly from a } \\
\text { tourist order organized by political } \\
\text { entities. Environmental and social } \\
\text { problems are beginning to be } \\
\text { perceived. The number of visitors no } \\
\text { longer grows so markedly. Actions to } \\
\text { maintain visitor indicators are aimed at } \\
\text { promoting offers and packages. } \\
\text { Foreign investments are consolidated. } \\
\text { There is a polarization of residents } \\
\text { supporting or not the growth of tourist } \\
\text { activity. }\end{array}$ & Consolidation \\
\hline $\begin{array}{l}\text { Visitors reach their highest level and } \\
\text { the increase stops, most are repetitive, } \\
\text { the hotel occupancy percentages } \\
\text { decrease, the sale or rental of } \\
\text { condominiums and residences begins, } \\
\text { the load capacity is threatened, } \\
\text { economic problems arise, } \\
\text { environmental and social conditions of } \\
\text { the destination and is the turning point } \\
\text { towards the Decline or Rejuvenation } \\
\text { stage. }\end{array}$ & Stagnation \\
\hline $\begin{array}{l}\text { In this stage, the tourist offer is } \\
\text { deteriorated, the average stay of } \\
\text { tourists falls, strategies to maintain } \\
\text { occupation by lowering prices become } \\
\text { common, it begins with the flight of } \\
\text { foreign capital, the tourist } \\
\text { infrastructure shows signs of } \\
\text { destruction that must be repaired or } \\
\text { replaced or in some cases they change } \\
\text { the tour to a non-touristic one. }\end{array}$ & Slope \\
\hline $\begin{array}{l}\text { Due to the repositioning, a redesign of } \\
\text { the destination's tourist offer is } \\
\text { presented, a revitalization is achieved } \\
\text { with a new national or foreign } \\
\text { investment for a more rational use of } \\
\text { resources. }\end{array}$ & Rejuvenation \\
\hline
\end{tabular}

Table 1. Stages of CVDT

Source: Adapted from (Butler, 2004), (Osorio, Deverdum, Mendoza, \& Benitez, 2019), (Diez, 2019)

SONDA-DE LA ROSA, Ricardo, RUIZ-LANUZA, Agustin and ALCUDIA-ROCHA, Josefina. Tourism area life cycle analysis in San Miguel de Allende Guanajuato. ECORFAN Journal-Republic of Peru. 2021 
The first application of the CVDT model in a case study was that of Hovinen (1982) in Lancaster County, Pennsylvania, opening the possibility that other destinations were diagnosed under the same model. Authors such as Choy (1992), Hamzah (1995), and Douglas (1997) have applied this theoretical model as a fundamental tool in the diagnosis and establishment of strategies in decision-making.

As time went by, several theorists naturally emphasized the limitations of Butler's model, making criticisms mainly in relation to: lack of operability, lack of measurement of load capacity, inconsistencies in the definition of one stage and another., the lack of standardized indicators by stage, the lack of considerations of order of sustainability and competitiveness of the destination, as well as the devaluation in the participation of the private initiative and lack of definition of territorial spatial characteristics, (Priestley \& Lluis, 1998), (Diedrich \& GarcíaBuades, 2009), (Aguiló, Alegre, \& Sard, 2005), (López, 2011), (Deery, Jago, \& Fredline, 2012), (Vera, Palomeque, Marchena, \& Antón, 2013), (Haywood, 1986).

The previous opinions encouraged Butler in 1991 to re-evaluate the proposed model by integrating future variables including: sustainability, dynamics of tourism development, process and management, as well as the measurement of the carrying capacity and spaces of the evaluated destination. Butler (2011) reconsidered the model again emphasizing external factors (attitude, technology, politics and economics) and internal factors (habits, tastes and preferences). These adjustments to the model have served so that other theorists, through their evaluations, enrich the model and have a greater approximation in the sum of tourism indicators that exceed the observed limitations and become a model that can be improved on a day-to-day basis. (Garay \& Cánoves, 2011), (Soares, Gandara, \& Ivars, 2012), (Yang, Ryan, \& Zhang, 2013), (Kristjánsdóttir, 2016).

As a result of the literature review, it can be observed that there is a high degree of similarity between Butler's model and the theorists who postulate it. In this sense, the model must be considered as a method of approximation in the explanation of a reality, without forgetting the peculiarities of each destination that is in principle unique and authentic.
Today, after observation and criticism, Butler's CVDT model is still valid because it still lacks theoretical elements beyond the 1980 assumption (Diez, 2019), so its convenience to analyze tourist destinations in a present situation is used in defining strategies when considering their current stage and projecting their future on the horizon.

\section{Methodology}

In order to analyze the evolution of tourist indicators that influence the current situation of the city of San Miguel de Allende and contrasting them with the CVDT model to identify the stage of evolution in which it is located, the basis is the methodological proposal of Jiménez and Jiménez (2015). This research is quantitative and descriptive in scope with a positive level of confidence that makes use of documentary review and analysis of texts and tourist indicators of an economic, social, cultural and urban order to identify the classification factors of the stages with respect to the model of the CVDT.

To search for the information, various primary and secondary sources of official sites were consulted: World Tourism Organization (UNWTO), National System of Statistical Information of the Tourism Sector (DataTur), Federal Secretary of Tourism (SECTUR), Secretary of Tourism of Guanajuato (SEDETUR Guanajuato), as well as web pages, databases, specialized magazines in the area of tourism related to the supply and demand of tourist activities in the city of San Miguel de Allende.

For the bibliographic review, tourist barometers, statistics from the National Institute of Statistics and Geography (INEGI) were consulted, as well as investigations in scientific magazines, official documents of the San Miguel de Allende City Council, critical notes and reports of the tourist activity of the Observatory Tourist of the state of Guanajuato.

After obtaining data, tables and graphs were prepared to show the behavior of the selected indicators and compare them with the situation of each stage of the CVDT model. The conscious and critical analysis resulted in the identification of the stage of evolution that the city of San Miguel de Allende is experiencing, provoking a deep reflection and discussion of the impacts that this has generated.

SONDA-DE LA ROSA, Ricardo, RUIZ-LANUZA, Agustin and ALCUDIA-ROCHA, Josefina. Tourism area life cycle analysis in San Miguel de Allende Guanajuato. ECORFAN Journal-Republic of Peru. 2021 


\section{Results}

The free and sovereign State of Guanajuato, see Figure 1, located in the north-central part of the Mexican Republic, with an area of $30,607 \mathrm{~km}^{2}$ represents $1.6 \%$ of the national territory. In 2015 , its population amounted to 5.8 million inhabitants, placing it as the sixth most populated entity in Mexico. It was founded on December 20, 1823.

San Miguel de Allende head of the municipality with the same name is one of the main destinations in the state. Declared a Magical Town in (2002) and in (2017) named by Travel + Leisure magazine as the best city in the world for its level of service, attention, gastronomic services, cleanliness, shopping and mobility that together with its architectural beauty and culture make this place an attractive and safe destination.

In 2008, the United Nations Educational, Scientific and Cultural Organization (UNESCO), the United Nations agency in charge of culture and education, declared the city of San Miguel de Allende under the title of Protective Villa of San Miguel and Sanctuary of Jesús Nazareno de Atotonilco, the distinction was awarded for its cultural and architectural contribution to the Mexican Baroque and its importance in the struggle for Mexican Independence from Spain.

In an atmosphere of provincial life with luxury and comfort, the city of San Miguel de Allende is an invitation to enter a cultural city with neo-Gothic towers from the seventeenth and eighteenth centuries, which were carved with pink quarry between cobbled streets in which there are large houses. Colonial buildings, some of them transformed into art galleries or museums, make it a picturesque and cosmopolitan city. Today, the city of San Miguel de Allende is one of the 46 municipalities that the State has; adding to the latter an area of almost $1,500 \mathrm{~km}^{2}$ and 171,857 inhabitants.

The proposed indicator analysis considers the following factors: Population analysis, Tourist influx, Connectivity, Hotel infrastructure, Occupancy indicators, Average stay, Complementary businesses, and economic spillover. In each figure the status is highlighted according to the stage of the CVDT model.

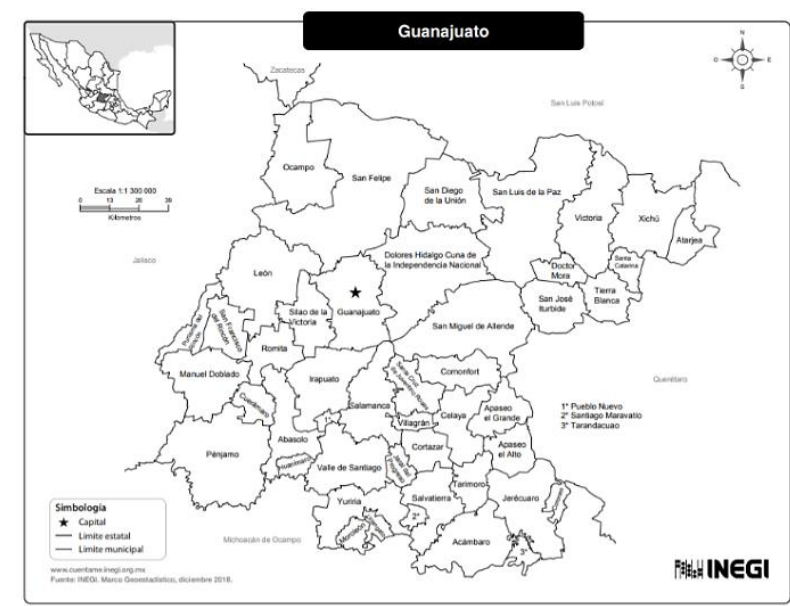

Figure 1 Guanajuato State and its municipalities Source: (National Institute of Statistics and Geography [INEGI])

\section{Population analysis}

The municipality of San Miguel de Allende, which houses the cultural city that bears his name, is located in the center of the State, has had a constant growth, having significant increases in 1990, 2000 and 2010 according to the Population and Housing Census carried out by the INEGI from 1950 to 1990 for decades and then five years, see Graphic 1.

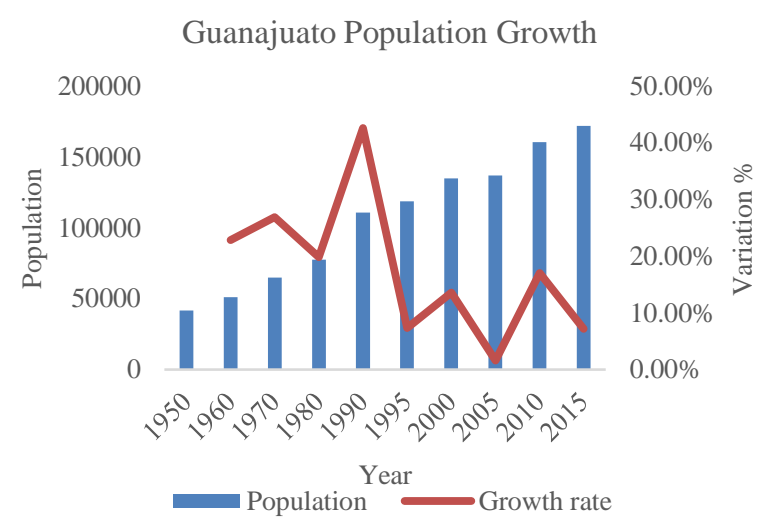

Graphic 1 Guanajuato population growth Source: (National Institute of Statistics and Geography [INEGI], 1952) (National Institute of Statistics and Geography [INEGI], 1963) (National Institute of Statistics and Geography [INEGI], 1971) (National Institute of Statistics and Geography [INEGI ], 1988) (National Institute of Statistics and Geography [INEGI], 1990) (National Institute of Statistics and Geography [INEGI], 1995) (National Institute of Statistics and Geography, 2000) (National Institute of Statistics and Geography [INEGI] , 2005) (National Institute of Statistics and Geography [INEGI], 2010) (National Institute of Statistics and Geography [INEGI], 2015)

In the fifties, the city of San Miguel de Allende had 41,571 inhabitants, which increased by $23 \%$ by the sixties. By the 1970 s, the population grew to $51,069,27 \%$. 
For the decade of the seventies and eighties the growth was constant in growth with 64,794 and 77,624 inhabitants respectively. In the 1990s, there was a significant increase, reaching 110,692 , a phenomenon that was replicated in 2000 with 134,880 and in 2010 with a population of 160,383 . The growth rate of the last 65 years is $1,313 \%$.

The economic growth of the city of San Miguel de Allende has brought benefits related to tourism to the inhabitants, however, for the original San Miguelenses they begin to question the accelerated transformation of spaces that were homes to tourist products, forcing an expansion accelerated population from the surrounding population, generating discontent among residents. Likewise, the social problems typical of a city that has grown in this way are present, as stated by Butler in the stagnation stage, where saturation is expressed in environmental terms (traffic problems, lack of land, water supply, quality of air or lack or failures of electrical energy), elements that for the city center is already common.

Although in the Figure it can express a constant growth numerically, in the geographical contexts of San Miguel de Allende, according to the CVDT model, its population growth behavior places it in the stagnation stage, since it already presents excessive carrying capacity in the city center, environmental wear and tear and social problems, which do not help tourist activity at all, main discontent among the original locals.

\section{Tourist influx}

The analysis of the arrival of tourists and the connectivity to a tourist destination go hand in hand, because if the second is developed, the first occurs as a consequence. In this last aspect, the city of San Miguel de Allende has registered a positive trend, since 1996, the year in which it registered 200,857 tourist arrivals (national and foreign), during the following years and until 2009 the average growth registered $25.2 \%$, year in which there is evidence of higher growth in its history from 2010 to 2017 with $177 \%$, which has decreased in 2018 and 2019, (DataTur, 2020), see Graphic 2.

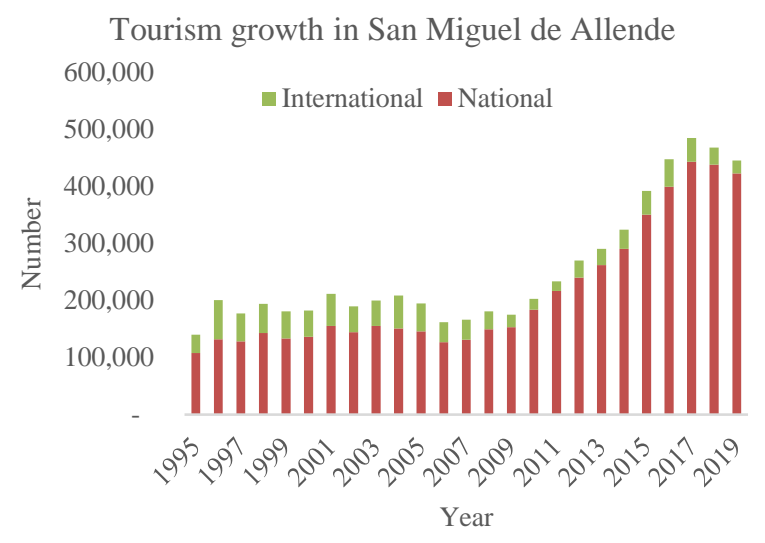

Graphic 2 Tourism growth in San Miguel de Allende Source: Adapted from (DataTur, 2020)

To commemorate the bicentennial of the country's independence, in 2010 strategies such as the "Guanajuato Centennial Passport 2010" were formulated, which resulted in an increase in visitors to the destination, where the change from tourists from excursions to tourists in organized groups was evident, laying the foundations of a rejuvenation initiating a recovery maintained until 2017 , mainly due to the diversification of its products due largely to municipal and state policies of rational use of resources, as well as changes in tastes, and expectations of tourist consumption by the demanding levels of quality in services, respect for the environment and the products they consume (García, Mielgo, \& Saco, 2010).

In the development of the tourist influx of the destination, an interesting fact is the main participation of national tourism, which in 2017 reached its highest point with more than 444 thousand people. On the other hand, international tourism, which in 1995 came to represent just over $10 \%$ of total tourists, the largest in its history so far, has remained on average the last decade (2009 to 2019) at $9 \%$.

According to the CVDT model, the evolution of visitors to San Miguel de Allende places it in the Stagnation stage.

\section{Connectivity}

It is necessary to complement the previous indicator with others, such as the means of access for tourists. Improved air and land connectivity in recent years has meant an opening to new tourist flows to the State. 
This clearly shows that tourists are transported mainly by land, either by private car or by bus, along the highways that connect municipalities, including other States, as Puig (2021) comments, regarding the empirical evidence regarding the contribution of tourism to development in emerging destinations, analyzing the socio-economic benefits reported by tourism specialization, see Graphic 3. It is also notable that the growth of arrival at the destination by air since 2016, has added new tourism markets that joins the traditional.

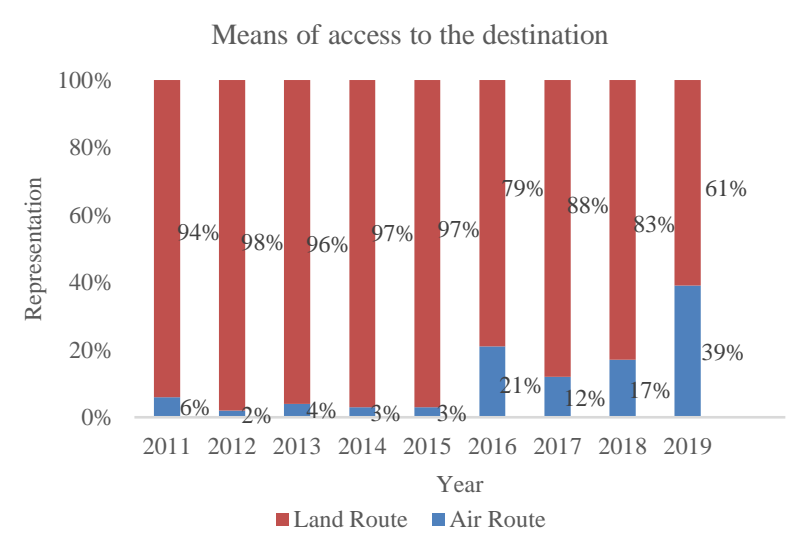

Graphic 3 Means of access to the destination Source: Adapted with data from the Tourism Observatory of the State of Guanajuato (2011); (2012); (2013); (2014); (2015); (2016); (2017); (2018); (2019)

The Bajío International Airport (IATA Code: BJX), operated by Grupo Aeroportuario del Pacífico, also known as Guanajuato International Airport, is located very close to the city of Silao, with a capacity to serve 26 flights per hour. This is considered one of the busiest in Mexico; Its privileged location, 90 minutes from the city of San Miguel de Allende, provides safe and high-quality transportation, making tourists who travel by air from national or international destinations consider this mode of access to the tourist destination.

After 2013, with the remodeling of the airport and the entry of low-cost flight companies to and from Bajío, the arrival by air to the city has been increasing, rebounding especially in 2016 where it increased 18 percentage points and in in 2019 reaching its historical maximum $38 \%$ of tourists who visit the destination. This has marked a new stage of tourism by air, which makes use of car rentals, minivans or local transport routes.
As a result of the analysis of these indicators and their evolution, the stage in which it is situated with respect to the CVDT is that of rejuvenation, due to the increase in air accessibility caused by various factors (travel policies, promotions, prices, supply and demand) and with This is a real opportunity to visit the destination and make use of the tourist infrastructure described below.

\section{Hotel infrastructure}

The analysis of the hotel and room supply of the city of San Miguel de Allende itself provides a key indicator that can place it in any of the stages of the CVDT. From 2011 to 2017, the number of hotel establishments has been increasing, a year in which there was a small setback, but quickly recovered in the following year, reaching its historical maximum with 165 in 2019. In this sense, it can be considered that it is in the consolidation stage. It is important to consider that despite the fact that in recent years they have been presented as an extra hotel offer: collaborative accommodation, or renting houses, or apartments by season, or those who stay with family or friends, it has not affected this indicator.

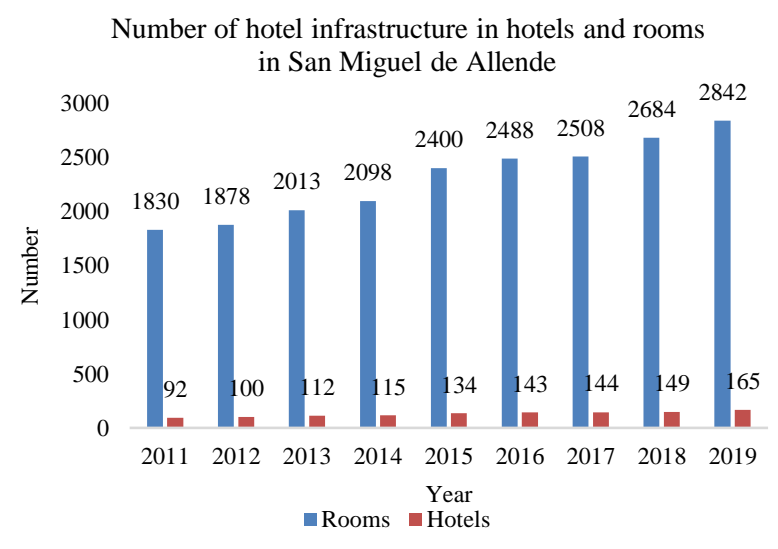

Graphic 4 Number of hotel infrastructure in hotels and rooms in San Miguel de Allende

Source: Adapted with data from the Tourism Observatory of the State of Guanajuato (2011); (2012); (2013); (2014); (2015); (2016); (2017); (2018); (2019)

However, if the number of rooms in these establishments is not included, the analysis of this variable cannot be considered complete, since as a whole since 2011 it has maintained a constant growth, the most favorable years being 2015 and 2019 according to the figures registered by the Observatory (2,842 rooms), see Graphic 4. 
The behavior of the number of rooms shows that when related to the CVDT model San Miguel de Allende has passed from the Development stage to the Consolidation stage, however, when considering the reduced territorial space in which the development is presented, it shows evident social characteristics of stagnation and even decline.

\section{Hotel occupancy}

Regarding the number of hotels and the availability of rooms, it is necessary to specify the occupancy rate of the accommodationoriented infrastructure, which will be illustrated in Figure 6 below.

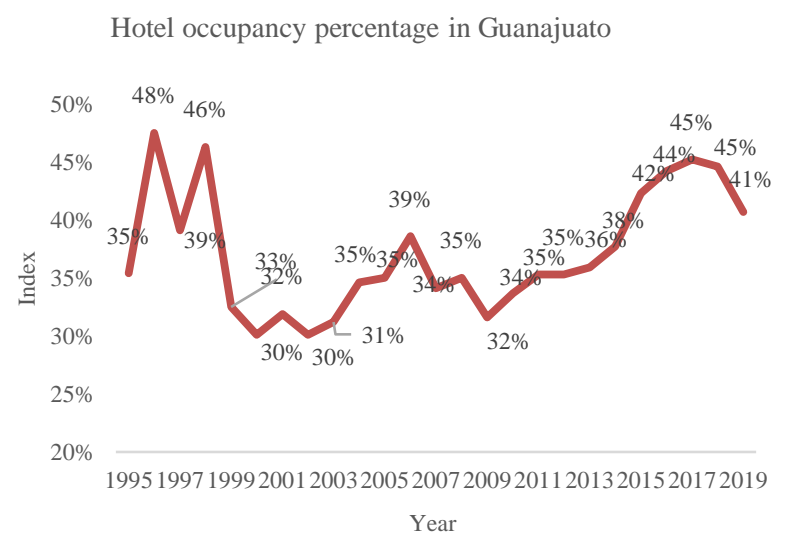

Graphic 5 Hotel occupancy percentage in Guanajuato Source: Adapted from (DataTur, 2020)

From 1995 to 2002, the hotel occupancy rate in San Miguel de Allende underwent erratic changes, and stabilized upwards reaching $39 \%$ occupancy in 2006, decreasing 7 percentage points in the next 3 years when it marked a recovery that Until 2018 it was positive, decreasing 3 percentage points in 2019.

With the previous data regarding the percentage of hotel occupancy in the destination, it is confirmed that it is in a stagnation stage according to the CVDT model and that, although the number of rooms is increasing, this is not the case in the occupancy percentages.

\section{Average stay}

The analysis of the occupancy percentage is complementary to that of the average stay of tourists who stay in the hotel infrastructure, as shown in Graphic 6.

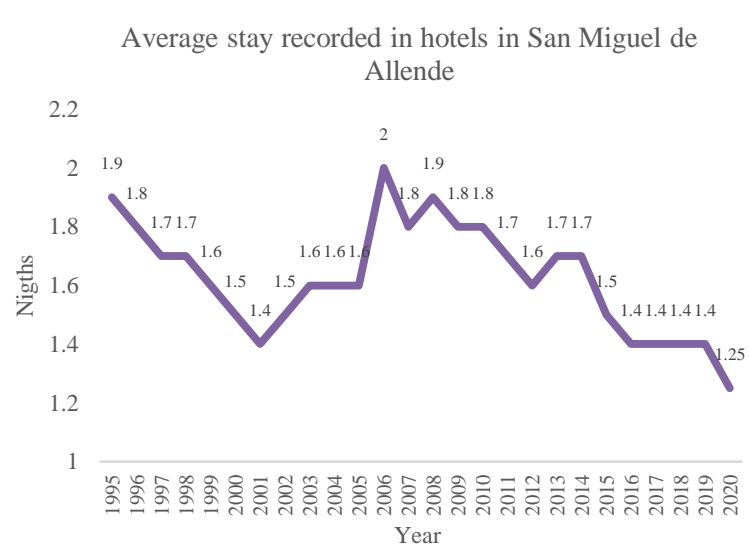

Graphic 6 Average stay recorded in hotels in San Miguel de Allende

Source: Adapted with data from the Tourism Observatory of the State of Guanajuato (2010); (2011); (2012); (2013); (2014); (2015); (2016); (2017); (2018); (2019) and (DataTur, 2020)

In all records since 1995, the average stay in the city of San Miguel de Allende is less than two nights with a marked trend of decrease from 1995 to 2001 and from 2006 to date. This indicator can be explained from different angles, although the stay in San Miguel de Allende is reduced, the connectivity between the two cities of Guanajuato can promote a tourist flow that is beneficial for the economic overflow of the state. It is important to note that the temporality or seasonality of the destination is significant and highly subject to holiday periods, as well as those on weekends where the stay is extended due to various scheduled socio-cultural events.

This semi-stable phenomenon of hotel accommodation refers to the Stagnation stage with respect to the Butler model, when tourists reach their highest level of stay and most of them become repetitive tourists who, as noted above, even start with the search for renting apartments or houses instead of established hotels, confirming Vena's position (2021) regarding that a tourist consumes a destination following the theory of nodes, visiting first what causes the visit and secondarily the expenses around them.

\section{Tourist establishments}

Although the hotel industry and the catering industry are considered the most representative, the other complementary elements of tourism activities described in Table 1 below should also be analyzed. 


\begin{tabular}{|c|c|c|c|c|r|r|r|}
\hline Year & $\begin{array}{c}\text { Unstable } \\
\text { foundations } \\
\text { total }\end{array}$ & Hotels & A\&B & Aux. Tur & Transport & Lease. \\
\hline 2020 & ND & ND & ND & ND & ND & ND \\
\hline 2019 & 823 & 165 & 233 & 1 & 34 & 2 \\
\hline 2018 & 174 & 149 & ND & ND & ND & ND \\
\hline 2017 & 420 & 144 & 95 & 1 & 27 & 2 \\
\hline 2016 & 462 & 143 & 51 & 10 & 14 & 2 \\
\hline 2015 & 393 & 134 & 82 & 1 & 15 & 2 \\
\hline 2014 & 369 & 115 & 95 & 1 & 27 & 2 \\
\hline 2013 & 367 & 112 & 95 & & 1 & 27 & 2 \\
\hline 2012 & 328 & 100 & 75 & & 3 & 27 & 2 \\
\hline 2011 & 269 & 92 & 92 & ND & 34 & 2 \\
\hline
\end{tabular}

\begin{tabular}{|c|c|c|c|c|c|}
\hline Year & Agencies & SPA & Turistic guides & Enclosures & Attractive \\
\hline 2020 & ND & ND & ND & ND & ND \\
\hline 2019 & 19 & 40 & 69 & 44 & 216 \\
\hline 2018 & ND & ND & 25 & ND & ND \\
\hline 2017 & 15 & 17 & ND & 16 & 103 \\
\hline 2016 & 12 & 29 & 14 & 17 & 170 \\
\hline 2015 & 15 & 20 & 10 & 18 & 96 \\
\hline 2014 & 15 & 17 & 9 & 16 & 72 \\
\hline 2013 & 15 & 17 & 9 & 16 & 73 \\
\hline 2012 & 15 & 17 & ND & 16 & 73 \\
\hline 2011 & 14 & ND & 22 & 6 & 7 \\
\hline
\end{tabular}

Table 1 Number of tourist establishments in San Miguel de Allende

Source: Adapted with data from the Tourism Observatory of the State of Guanajuato (2011); (2012); (2013); (2014); (2015); (2016); (2017); (2018); (2019)

According to the statistics of the Tourism Observatory of the State of Guanajuato, the total number of tourist establishments in general has been constantly increasing. Figure 8 describes by categories the establishments in: Hotels, A and B (restaurants, cafeterias), Tourist Assistance Services (information modules, cranes, mechanics, automotive services, vulcanizers), Transporters, Car rental companies, Travel agencies, Spas, Tourist guide services, Venues (auditoriums, lounges) and Attractions (stadiums, museums, galleries, shops, markets).

A characteristic of the CVDT stage in decline is the price reduction strategy to maintain the operation of tourism products and services amid the varied competition in the market. San Miguel de Allende shows characteristics of great supply and less and less demand, so the Decline stage in this sense is evident.

\section{Economic spill}

Creating jobs and thus sources of income for the community does not necessarily demonstrate sustainable and positive growth, since the oversaturation of services and products can become a problem of supply and demand, since what is sought is to maintain a fair balance.
In the case of San Miguel de Allende there is an imbalance, given that there is a parallel offer of unregistered products and services that are operating in the city, informal commerce, family establishments that do not reach the category of businesses or simply the independent premises that offer services without being registered or regulated by the municipality.

These formal businesses, and the informal ones in the same way, make tourists have an explained economic benefit, which is outlined in Graphic 7.

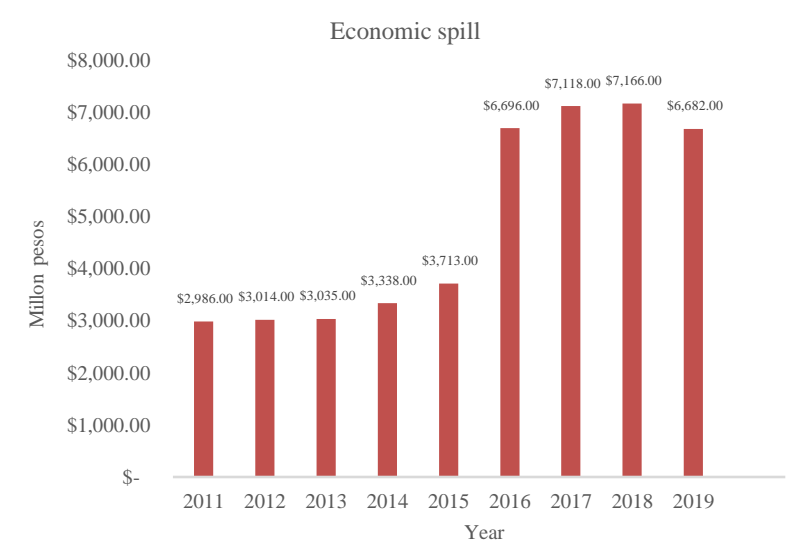

Graphic 7 Economic spill of Guanajuato

Source: Adapted with data from the Tourism Observatory of the State of Guanajuato (2011); (2012); (2013); (2014); (2015); (2016); (2017); (2018); (2019)

Regarding the economic spill in the city of San Miguel de Allende, this is as variable as it is interesting: in 2011 it was the year with the lowest spill, with only 2,986 million pesos; However, for the following year and thereafter there has been continuous growth, which for 2016 was very significant, increasing almost $100 \%$, reaching 7,166 million pesos in 2018, a historical figure for the city and a boom in commercial activities that was overshadowed by the end of 2019, when it fell to about 6,682 million pesos.

In the last 5 years, the economic spill of San Miguel de Allende has remained in the range of 6,000 to 7,000 million pesos and that in 2020 an average spill is estimated, therefore, in this sense, the CVDT model is situated in Consolidation stage. 


\section{Comprehensive analysis}

By analyzing the information, it is possible to locate some indicators of the city of San Miguel de Allende in certain stages and place some indicators in other stages. However, globally the destination was in the Consolidation stage, after the commemorative activities developed in 2010 around the bicentennial of Independence and the centenary of Revolution. After five years, in 2015 it entered a stage of Stagnation, with appreciations towards Decline in aspects related to traditional tourist infrastructure, and of Rejuvenation in aspects such as a diversified offer with complementary services and its own evolution of extra-hotel accommodation.

Although the area of the historic center retains its charm, it has ceased to be a residential area to become a commercial area, and with it the loss of landscapes of a traditional town is being transformed into a commercial one, deteriorating the image of the destination. However, diversified services around cultural tourism are on the rise, hosts of festivals of international stature mean that the city of San Miguel de Allende does not lose the magic that has characterized it since its origins.

In the documentary analysis on the evolution of tourist indicators that influence the present condition of the city of San Miguel de Allende, comparing it with the CVDT model and its corresponding stages, it would be risky to determine a single stage with respect to the CVDT model since it does not There are sufficient studies to determine the carrying capacity, ecological standards and consumption of official and unofficial products and services, so that the economic, cultural, territorial and social elements can have individual stages of development, consolidation, stagnation, decline or rejuvenation. inviting individualized implementation for each of the variables in a great inclusive strategy to improve the destination.

\section{Conclusions}

This work uses the CVDT model as a starting point in the city of San Miguel de Allende depending on the stages it is in to address the problem of lack of a comprehensive tourism strategy that promotes sustainable tourism development.
From the results of the evaluation of the city of San Miguel de Allende, it is concluded in a global way that the Exploration and Involvement stage (before 1990) has been passed, as well as the Development stage (1990 to 2009) and the of Consolidation (2010 to 2014), currently in the Stagnation stage (since 2015), with specific features of Decline (decrease in average stay, concentration of temporality, change in the profile of visitors and tourists, deterioration of the traditional tourist plant, and damage to the environment) and Rejuvenation at the same time (diversification of products related to culture and heritage).

The security crisis throughout Mexico and in particular in the state of Guanajuato is a permanent factor in consideration for tourists and visitors, the warnings of the United States to its citizens about trips to Mexico do not favor the flow of tourists to the city, for what the prevention and visitor care measures adopted by the State, through its promotional programs, have a direct impact on visitor perception, with the objective of minimally having a negative impact on tourism indicators.

The connectivity that the State and the city of San Miguel de Allende presents has attracted tourists of all socioeconomic levels who have found a variety of options from hostels to grand tourism hotels or high-level residential tourism, where the massive influx of tourists has contributed to the growth of the local economy. In recent years, San Miguel de Allende, as a cultural destination par excellence, has entered the romance and wedding segments, as well as incentive trips, and congresses and conventions. Destinations such as San Miguel de Allende must consider that the financial and economic crisis in the world and in Mexico should be the engine of evolution to establish strategies that serve specific segments where Guanajuato is a leader, increasing personalized services that will be reflected in the satisfaction of tourists and locals.

San Miguel de Allende is considered one of the national leaders in cultural tourism, so it has to create a higher status by promoting authentic attributes of its city, architecture and landscapes, making planned strategies to diversify products with the same premise without altering its heritage product that allow to market and promote said offer involving all the agents involved in the tourism model. 
With this summary of indicators that feed the analysis of the CVDT model for the city of San Miguel de Allende, local governments can make use of the information to redirect actions towards the regeneration of a destination that integrates the private (commercial) sector and the resident community. Participate directly or indirectly in the consolidation and innovation of the tourist offer, assuming benefits and responsibilities in sustainable, fair and equitable exercises in the long term, since according to (Domareski, 2015), the organization of a territory must be seen and analyzed through the integration of the perspective between the different social dimensions.

Sustainable development must be considered as a strategic project of a tourist destination, combining the collective actions of communities, government entities and private initiatives to create cultural meaning with real expressions that can be truly commercialized and generate economic benefits for the entire destination.

A proposal that arises to follow up on this analysis is related to the application of a Balanced Scorecard for decision making that allows the development of sustainability strategies for a destination as described by Carvajal (2021) through a detailed discussion that can provide a clear vision of practical requests in the objects of study.

The results of this research will be useful once the city of San Miguel de Allende establishes its horizon in the immediate evolution, aware of its problems and areas of opportunity, the management and tourism development of the destination will impact the state and national tourism indicators by This establishes a basis for future research for other tourist destinations due to the replicability of the tool and diagnosis carried out taking into account the needs of tourist rethinking in this new normality. The final comment addresses the challenges facing the tourism sector today, those destinations that triumph will be those that provide reliable and personalized services to tourists who today are more demanding and have greater access to information, globalized tourists. that transcend borders and that seek not only products or services, but also maintain close contact with the places they visit, where products and services can make them experience, excite and become the protagonists of their travels.

\section{References}

Aguilar, C. (2009). El ciclo de vida de un destino turísticos: Puerto Vallarta, Jalisco, México. CULTUR: Revista de Cultura y Turismo(1), 124.

Aguiló, E., Alegre, J., \& Sard, M. (2005). The persistence of the sun and sand tourism model. 26(2),

219-231.

doi:10.1016/j.tourman.2003.11.004

Banco de México. (2021). Banxico. Obtenido de Saldo e Ingreso: https://www.banxico.org.mx/SieInternet/consult arDirectorioInternetAction.do?accion=consultar CuadroAnalitico\&idCuadro $=$ CA198\&sector $=1$ \&locale $=\mathrm{es}$

Butler, R. (1980). The concept of tourism area cicle of evolution: Implications for managment of resources. (2006 ed., Vol. 1). Clivendon USA: Channel view Publications.

Butler, R. (2004). The Tourism area life cylce in the twenty-first century. A companion to tourism, 159 - 170. Obtained from: https://onlinelibrary.wiley.com/doi/abs/10.1002 /9780470752272.ch13

Butler, R. (2011). Tourism area life cycle. Contemporary Tourism Reviews, 1-33.

Carvajal, G.; Chávez, A.; Rivera, D. \& Almeida, E. (2021). Cuadro de Mando Integral para la toma de decisiones y desarrollo de estrategias de sustentabilidad de un destino turístico. Journal of Business and Entrepreneurial Studie, 5(1), 113-134. https://doi.org/10.37956/jbes.v5i1.164

Choy, D. (1992). Life cycle models for Pacific island destinations. Journal of Travel Research, 30(3), 26-31.

Cohen, E. (1979). A Phenomenology of Tourist Experiences. Sociology, 13(2), 179-201. doi: $10.1177 / 003803857901300203$

CONACULTA. (2002). Guías del patrimonio cultural y turismo. Obtained from: https://patrimonioculturalyturismo.cultura.gob. mx/guias/guia7_5.php 
Cristaller, W. (1963). Some Considerations of Tourism Location in Europe: The peripheral Regions - Underdeveloped countries Recreation Areas. Regional Science Association papers(12), 95-105.

DataTur. (2020). Actividad Hotelera en Centros Turísticos Seleccionados por Categoría. Obtained from: www.datatur.sectur.gob.mx/SitePages/Activida dHotelera.aspx

Deery, M., Jago, L., \& Fredline, L. (2012). Rethinking social impacts of tourism research: A new research agenda. Tourism Management, $33(1)$, 64-73.

doi:10.1016/j.tourman.2011.01.026

Diedrich, A., \& García-Buades, E. (2009). Local perceptions of tourism as indicators of destinations decline. Tourism Management, 30(4), 1-10.

Diez, V. (2019). El modelo de ciclo de vida de los destinos turísticos vigencia, críticas y adaptaciones al modelo Butler. 17, 19-34.

Domareski, T. (2015). A dinâmica evolutiva da competitividade do destino turístico Curitiba. Tese apresentada como requisito a obtencao do grau do Doutor em Geografia. Universidad Federal do Paraná.

Douglas, N. (1997). Applying the life cycle model to Melanesia. Annals of Tourism Research , 34(1), 1-22.

Doxey, G. (1975). A causation theory of visitorresident irritants: Methodology and research inferences. Sixth annual conference proceedings of the Travel Research Association. San Diego, USA.

Expansión. (2017). expansion.mx. Obtenido de https://expansion.mx/tendencias/2017/07/12/san -miguel-de-allende-es-nombrada-la-mejorciudad-del-mundo

Garay, L., \& Cánoves, V. (2011). Life cycles, stages and tourism history. The Catalonia (Spain) experience. Annals of Tourism Research, 38(2), 651-671. doi:10.1016/j.annals.2010.12.006
García, B., Reinares, E., \& Armelini, G. (enerojunio de 2013). Ciclo de vida de los destinos turísticos y estrategias de comunicación: los casos de España y Chile. aDResearch, 7(7), 7693. doi:10.7263/ADR.004.01.5

García, H., Mielgo, A., \& Saco, M. (2010). El desafio del sector turístico español: reposicionamiento de la oferta y retos promocionales para la adaptación a los nuevos segmentos. Actas del $11^{\circ}$ Forum Internacional sobre Las Ciencias, las Técnicas y el Arte aplicadas al Marketing (págs. 121-142). Academia y Profesión.

García-Ayllon, S. (2015). Geographic Information System (GIS). Analysis of impacts in the tourism area life cycle (TALC) of a Mediterranean Resort. International Journal of Tourism Research, 18, 186-196. doi:10.1002/jtr.2046

Guanajuato, O. T. (2010). Perfil del Visitante a la Ciudad de Guanajuato 2010. Obtained from: http://www.observatorioturistico.org/publicacio nes

Guanajuato, O. T. (2011). Perfil del Visitante a la Ciudad de San Miguel de Allende 2011. Obtained from: http://www.observatorioturistico.org/publicacio nes

Guanajuato, O. T. (2012). Perfil del Visitante a la Ciudad de San Miguel de Allende 2012. Obtained from: http://www.observatorioturistico.org/publicacio nes

Guanajuato, O. T. (2013). Perfil del Visitante a la Ciudad de San Miguel de Allende 2013. Obtained from: http://www.observatorioturistico.org/publicacio nes

Guanajuato, O. T. (2014). Perfil del Visitante a la Ciudad de San Miguel de Allende 2014. Obtained from: http://www.observatorioturistico.org/publicacio nes

Guanajuato, O. T. (2015). Perfil del Visitante a la Ciudad de San Miguel de Allende 2015. Obtained

from: http://www.observatorioturistico.org/publicacio nes 
Guanajuato, O. T. (2016). Perfil del Visitante a la Ciudad de San Miguel de Allende 2016. Obtained from: http://www.observatorioturistico.org/publicacio nes

Guanajuato, O. T. (2017). Perfil del Visitante a la Ciudad de San Miguel de Allende 2017. Obtained from: http://www.observatorioturistico.org/publicacio nes

Guanajuato, O. T. (2018). Perfil del Visitante a la Ciudad de San Miguel de Allende 2018. Obtained from: http://www.observatorioturistico.org/publicacio nes

Guanajuato, O. T. (2019). Perfil del Visitante a la Ciudad de San Miguel de Allende 2019. Obtained from: http://www.observatorioturistico.org/publicacio nes

Hamzah, A. (1995). The changing tourist motivation and its implications on the sustainability of small-scale tourism development in Malaysia. World Conference on Sustainability Tourism. Lanzarote, Spain.

Haywood, M. (1986). Can the tourist-area life cycle be made operational? Tourism Management, 7(3), 154-167.

Hovinen, G. (1982). Visitor cycles: Outlook for tourism in Lancaster Country. Annals of Tourism Research, 9(4), 565-583.

Instituto Nacional de Estadística y Geografía [INEGI]. (1952). Séptimo Censo General de Población. 6 de junio de 1950. Estado de Guanajuato. Obtenido de INEGI Publicaciones: https://www.inegi.org.mx/app/biblioteca/ficha.h tml?upc $=702825412203$

Instituto Nacional de Estadistica y Geografia [INEGI]. (1963). VIII Censo General de Población 1960. 8 de junio de 1960. Estado de Guanajuato. Obtenido de INEGI Publicaciones: https://www.inegi.org.mx/app/biblioteca/ficha.h tml?upc $=702825412876$
Instituto Nacional de Estadística y Geografía [INEGI]. (1971). IX Censo General de Población 1970. 28 de enero de 1970. Obtained from INEGI Publications: https://www.inegi.org.mx/app/biblioteca/ficha.h tml?upc $=702825413279$

Instituto Nacional de Estadística y Geografía [INEGI]. (1988). X Censo General de Población y Vivienda 1980. Obtained from INEGI Publications:

https://www.inegi.org.mx/app/biblioteca/ficha.h tml?upc $=702825415563$

Instituto Nacional de Estadística y Geografía [INEGI]. (1990). XI Censo General de Población y Vivienda 1990. Obtained from INEGI Publications: http://internet.contenidos.inegi.org.mx/contenid os/productos/prod_serv/contenidos/espanol/bvi negi/productos/historicos/1290/702825415938/ 702825415938_1.pdf

Instituto Nacional de Estadística y Geografía [INEGI]. (1995). Conteo de Población y Vivienda 1995: Resultados definitivos. Obtained from INEGI Publications: https://www.inegi.org.mx/contenidos/productos /prod_serv/contenidos/espanol/bvinegi/product os/historicos/2104/702825492519/7028254925 19_1.pdf

Instituto Nacional de Estadística y Geografía [INEGI]. (2005). II Conteo de población y vivienda 2005. Obtained from INEGI Publications:

https://www.inegi.org.mx/contenidos/programa s/ccpv/2005/tabulados/Cont2005_NAL_Poblaci on.pdf

Instituto Nacional de Estadística y Geografía [INEGI]. (2010). Censo de Poblacion y Vivienda 2010. Obtained from INEGI Publications: https://www.inegi.org.mx/contenidos/programa s/ccpv/2010/tabulados/Basico/01_01B_MUNIC IPAL_11.pdf

Instituto Nacional de Estadística y Geografía [INEGI]. (2015). Censo de número de habitantes. Obtained from INEGI Publications: http://cuentame.inegi.org.mx/monografias/infor macion/gto/poblacion/ 
Instituto Nacional de Estadistica y Geografía [INEGI]. (s.f.). Mapa de Guanajuato. División Municipal. Obtenido de Cuéntame INEGI: http://cuentame.inegi.org.mx/mapas/pdf/entidad es/div_municipal/gtompios.pdf

Instituto Nacional de Estadística y Geografía. (2000). XII Censo General de Población y Vivienda 2000. Obtenido de INEGI Publicaciones:

https://www.inegi.org.mx/contenidos/productos /prod_serv/contenidos/espanol/bvinegi/product os/censos/poblacion/2000/resultadosporlocalida d/INITER11.pdf

Jiménez, L., \& Jiménez, W. (2015). Turismo tendencias globales y planificacion estrategica. Bogota: ECOE. Obtenido de https://www.ecoeediciones.com/wpcontent/uploads/2015/08/Turismo.-tendenciasglobales.pdf

Kristjánsdóttir, H. (2016). Can the Butler's tourist area cycle of evolution be applied to find the maximum tourism level? A Comparison of Norway and Iceland to other OECD countries. Scandinavian Journal og Hospitality and Tourism, 16(1), 61-75. doi:10.1080/15022250.2015.1064325

Lee, Y., \& Weaver, D. (2014). The tourism area life cycle in Kim Yujoeng Literary Village, Korea. Asia Pacific Journal of Tourism Research(19), 181-198. doi:10.1080/10941665.2012.735681

López, V. M. (2011). ¿El mismo modelo para siempre? Comentarios sobre el ciclo de vida del área turística a partir de la experiencia de Bahías de Huatulco (México). Obtenido de Seminario Internacional Renovación y Reestructuración de Destinos Turísticos Consolidados del Litoral: https://rua.ua.es/dspace/bitstream/10045/20511/ 1/Seminario_Renovestur_01.pdf

Michailidou, A. V., Vlachokostas, C., Moussiopoulos, N., \& Maleka, D. (2016). Life cycle thinking used for assessing the environmental impacts of tourism activity for a Greek tourism destination. Journal of Cleaner Production, 111(B), 499-510. doi:10.1016/j.jclepro.2015.09.099
OMT. (2019). Panorama del turismo internacional 2019. Obtained from: https://doi.org/10.18111/9789284421237

Osorio, M., Deverdum, M., Mendoza, M., \& Benitez, J. (2019). La evolución de IxtapaZihuatanejo, México, desde el modelo del ciclo de vida del destino turístico. Región y sociedad, 31. Obtained from: https://doi.org/10.22198/rys2019/31/1012

Plog, S. (1973). Why Destination Areas Rise and Fall in Popularity? The Cornell Hotel and Restaurant Administration Quarterly. 14(4), 5558.

Priestley, G., \& Lluis, M. (1998). The post Snagnstion Phase of the Resort Cycle. Annals of Tourism Research, 25(1), 85-111.

Puig, M. \& Foronda, C. (2021). Especialización turística en destinos emergentes latinoamericanos: Explorando el algoritmo para un longevo e inclusivo desarrollo socioeconómico. Revista de geografía Norte Grande, (78), 299321. https://dx.doi.org/10.4067/S071834022021000100299

Segrado, R. (2011). Etapas del ciclo de vida del destino turístico Cozumel (México). En J. F. Rebollo (Ed.), Seminario Internacional Renovación y Reestructuración de Destinos Turísticos Consolidados del Litoral. Alicante: Universidad de Investigaciones Turísticas; Universidad de Alicante.

Shida, O., Abdul, O., Badaruddin, M., \& Azizi, B. (2015). Coastal resort life cycle: An overview of Tioman Island, Malaysia. Tourism Planning \& Development , 12(3), 266-280. doi:10.1080/21568316.2014.947438

Soares, J. C., Gandara, J. M., \& Ivars, J. (2012). Indicadores para analizar la evolución del ciclo de vida de los destinos turísticos litorales. Investigaciones Turísticas(3), 19-38. doi:10.14198/INTURI2012.3.02

Vena Oya, J., Castañeda García, J. A. y Rodríguez Molina, M. Á. (2021). Análisis de la dispersión del gasto turístico en destinos sobreexplotados a través del uso de nuevas tecnologías: el caso de Granada, España. Investigaciones Turísticas (21), pp. 106-127. https://doi.org/10.14198/INTURI2021.21.6 
Vera, F., Palomeque, F. L., Marchena, M., \& Antón, S. (2013). Análisis territorial del turismo y planificación de destinos turísticos. Valencia: Tirant Humanidades.

Vernon, R., \& Wells, L. (1966). Internacional trade and international investment in the product life cycle. Quartery Journal of Economics, 81(2), 190-207.

Yang, J., Ryan, C., \& Zhang, L. (2013). Social conflict in communities impacted by tourism. Tourism Management, 35, 82-93. doi:10.1016/j.tourman.2012.06.002 